\title{
Prevalence and factors associated with depressive symptoms in individuals living with HIVIAIDS
}

\author{
Renata Karina Reis, ${ }^{1}$ Elizabete Santos Melo, ${ }^{1}$ Carolina de Castro Castrighini, ${ }^{1}$ \\ Marli Terezinha Gimeniz Galvão, ${ }^{2}$ Silmara Elaine Toffano-Malaguti, ${ }^{3}$ Elucir Gir ${ }^{1}$
}

1 Ribeirão Preto College of Nursing, University of São Paulo, São Paulo, Brazil.

2 Nursing Department, Federal University of Ceará, Ceará, Brazil.

${ }^{3}$ Nursing Department, Federal University of Triangulo Mineiro, Minas Gerais, Brazil.

Correspondence:

Renata Karina Reis

Bandeirantes Avenue, 3900

Monte Alegre,

Ribeirão Preto, São Paulo, Brazil

Phone: 55+ 1633150534

E-mail: rkreis@eerp.usp.br

Received first version: September 18, 2016; second version: January 27, 2017; accepted: February 27, 2017.

https://doi.org/10.17711/ SM.0185-3325.2017.008

\begin{abstract}
Introduction. Symptoms of depression are highly prevalent among people living with HIVIAIDS in Brazil and in other countries. This situation points to the need for proper diagnosis and timely treatment by the health team. Objective. To identify the prevalence of depressive symptoms and its association with sociodemographic, clinical and behavioral disorders among PLWHA. Method. This cross-sectional study analyzed 331 people living with HIVIAIDS in the city of São Paulo, Southeast Brazil. The Beck Depression Inventory was used to assess depressive symptoms. To identify predictors of depression, a multiple regression model was used, with a 95\% confidence interval. Results. Of the participants, $167(50.5 \%)$ were men, with an average age of 40 . Depressive symptoms were prevalent in $42.3 \%$ and the factors associated with depression were being employed, age, and immunological status. Being employed was 1.8 times more likely $(95 \% \mathrm{Cl}[1.0,2.8])$ to develop depressive symptoms than those who were not employed. The odds ratio of individuals under the age of 40 indicates they were 1.8 times more likely $(95 \% \mathrm{Cl}[1.1,2.8])$ to have depressive symptoms than those over 40 years old. In regard to clinical aspects, individuals with 200 CD4 cells per mm ${ }^{3}$ are 2.1 times $(95 \% \mathrm{Cl}[1.1,3.9])$ more likely to develop depression. Discussion and conclusion. We conclude that the prevalence of depressive symptoms among people living with HIVIAIDS was $42.3 \%$ and it was associated with being employed, age and CD4 + cell count.
\end{abstract}

Keywords: Depression, HIV, mental health, public health.

\section{RESUMEN}

Introducción. Los síntomas de depresión son muy prevalentes entre las personas que viven con el VIH/ SIDA en Brasil y en otros países. Esta situación apunta a la necesidad de un diagnóstico adecuado y un tratamiento oportuno por parte del equipo de salud. Objetivo. Identificar la prevalencia de síntomas depresivos y su asociación con trastornos sociodemográficos, clínicos y conductuales entre PVVS. Método. En este estudio transversal se analizaron 331 personas que vivían con VIH/SIDA en la ciudad de São Paulo, Sureste de Brasil. El Inventario de Depresión de Beck se utilizó para evaluar los síntomas depresivos. Para identificar predictores de depresión, se utilizó un modelo de regresión múltiple, con un intervalo de confianza del 95\%. Resultados. De los participantes, 167 (50.5\%) fueron hombres, con una edad promedio de 40 años. Los síntomas depresivos fueron prevalentes en el $42.3 \%$ y los factores asociados a la depresión fueron: empleo, edad y estado inmunológico. Estar empleado tenía 1.8 veces más probabilidades (IC 95\% [1.0, 2.8]) de desarrollar síntomas depresivos que aquellos que no estaban empleados. El odds ratio de individuos menores de 40 años indica que tenían 1.8 veces más probabilidades (IC 95\% [1.1, 2.8]) de tener síntomas depresivos que los mayores de 40 años. En cuanto a los aspectos clínicos, los individuos con 200 células CD4 por mm ${ }^{3}$ son 2.1 veces (IC 95\% [1.1, 3.9]) con mayor probabilidad de desarrollar depresión. Discusión y conclusión. Se concluye que la prevalencia de síntomas depresivos entre las personas que viven con el VIH / SIDA fue del $42.3 \%$ y se asoció con el empleo, la edad y el recuento de células CD4 +.

Palabras clave: Depresión, VIH, salud mental, salud pública. 


\section{INTRODUCTION}

Despite all the scientific knowledge gathered so far, the important therapeutic advance that contribute to the management as a chronic condition of the infection by the human immunodeficiency virus, and the universal access to treatment and social benefits achieved, People living with HIV/ AIDS (PLWHA) still face prejudicial situations in their family, social context (Silva, Moura \& Pereira, 2013), and assistance services, and often live in isolation with difficulties to start new emotional, social, and sexual relationships, as well as sharing the diagnosis of HIV infection, with fear of abandonment and rejection (Reis et al., 2011). Furthermore, PLWHA also experience difficulties to resume or maintain their life projects and often experience conflict and embarrassing situations, vulnerability, and the violation of their human rights (Ministry of Health, 2012).

Symptoms of depression are highly prevalent among people living with HIV/AIDS in Brazil and in other countries (Israelski et al., 2007; Reis et al., 2011; Silveira et al., 2012). The present study demonstrates the variables associated with depressive symptoms and it contributes results that point to the need for proper diagnosis and timely treatment by the health team.

Depression may precede the diagnosis and be associated with HIV infection risk factors; however, living with HIV/AIDS may exacerbate episodes of depression (Sherr, Clucas, Harding, Sibley \& Catalan, 2011). Depressive symptoms are a common mental disorder characterized by sadness, loss of interest and feelings of guilt which impair an individual's ability to cope with life (World Health Organization, 2010) and his/her quality of life (Reis et al., 2011).

In view of the previous discussion, the objective of this study was to identify the prevalence of depressive symptoms and its association with sociodemographic, clinical, and behavioral disorders among PLWHA. In this way, it is possible to identify the factors related to the highest depression rate in order to increase the assistance provided with prevention measures and to improve the quality of life.

\section{METHOD}

\section{Study design and study sample}

This cross-sectional study was conducted in outpatient clinics specializing in care provided to PLWHA located in Ribeirão Preto, São Paulo, Brazil. Participants in the study were individuals with HIV/AIDS, users of the public health system and registered in the services under study, and who met the following inclusion criteria: being aware of the HIV/AIDS diagnosis; being 18 years old or older; being monitored in the outpatient clinics under study; and having attended their medical visits scheduled during the study period.

\section{Measures}

The study sample consisted of 331 individuals with HIV/ AIDS that met the inclusion criteria and attended a medical consultation. The variables of interest in the present study were: sociodemographic (sex, age, education, income and employment), clinical (CD4 cell count, comorbidities), behavioral (alcohol consumption) and symptoms of depression.

\section{Procedures}

Participants were individuals with HIV/AIDS, users of the public health system, who were attended in the period from March 2007 to December 2010, on days of blood collection and medical appointment twice a week, who were under a clinical outpatient follow-up in two Specialized Care services that met the inclusion criteria. Data were collected by a nurse and a nursing student through individual interviews and use of medical records to clinical variables, using an instrument addressing socio-demographic, clinical, and behavioral variables.

The Beck Depression Inventory (BDI), created by Beck et al. in 1961 to assess the intensity of depression, was translated and validated in Portuguese (Andrade, Gorenstein, Vieira Filho, Tung \& Artes, 2001). This self-applied version, composed of 21 items, was used to assess symptoms of depression such as cognitive attitudes toward states like sadness, pessimism, feeling of failure, lack of satisfaction, feelings of guilt, punishment, self-dislike, self-accusation, suicidal ideas, crying spells, irritability, impaired social interaction, indecisiveness, distorted body image, work inhibition, loss of appetite, weight loss, somatic preoccupation, and decreased libido.

The instrument's minimum score for each item is 0 and the maximum is 3 , where 0 means the lack of depressive symptoms and 3 indicates the presence of symptoms. The final score was obtained by the sum of all points.

There are different cut-off points in the literature to classify depressive symptoms, but the ones adopted in this study were: from 0 to 10 points indicate absence or minimal symptoms of depression, and 11 to 63 indicates symptoms of depression (Gomes-Oliveira, Gorenstein, Lotufo Neto, Andrade \& Wang, 2012).

Confidentiality of the participants' identities and information was ensured. Data were collected after free and informed consent forms were signed and the Institutional Review Board approved the study, according to recommendations of Resolution 196/96, National Council of Health.

\section{Statistical analysis}

The database was processed and analyzed using the IBM ${ }^{\circledR}$ SPSS, version 17.0. Descriptive and analytical statistics were used in the data analysis. Univariate analysis was 
Table 1

Distribution of sociodemographic, clinical and behavioral variables and their association with symptoms of depression $(\mathrm{n}=331)$

\begin{tabular}{|c|c|c|c|c|c|c|c|c|c|}
\hline \multirow[b]{2}{*}{ Variables } & \multicolumn{4}{|c|}{ Symptoms of depression } & \multirow[b]{2}{*}{ Total } & \multirow[b]{2}{*}{$p$} & \multirow[b]{2}{*}{ Value } & \multirow{2}{*}{\multicolumn{2}{|c|}{$95 \% \mathrm{Cl}^{\ddagger}$}} \\
\hline & \multicolumn{2}{|c|}{$\begin{array}{l}\text { Without } \\
(n=191)\end{array}$} & \multicolumn{2}{|c|}{$\begin{array}{c}\text { With } \\
(n=140)\end{array}$} & & & & & \\
\hline \multicolumn{10}{|l|}{ Sex } \\
\hline Men & 86 & $52.4 \%$ & 78 & $47.6 \%$ & 167 & $.055^{\star}$ & 1.536 & .99 & 2.38 \\
\hline Women & 105 & $62.5 \%$ & 62 & $37.1 \%$ & 164 & & & & \\
\hline \multicolumn{10}{|l|}{ Age } \\
\hline$\leq 40$ & 121 & $53.5 \%$ & 105 & $46.5 \%$ & 226 & $.024^{*}$ & 1.736 & 1.07 & 2.81 \\
\hline$>40$ & 70 & $66.7 \%$ & 35 & $33.3 \%$ & 105 & & & & \\
\hline \multicolumn{10}{|l|}{ Education } \\
\hline$\leq 8$ & 115 & $54.2 \%$ & 97 & $45.8 \%$ & 212 & $.089^{*}$ & 1.491 & .94 & 2.37 \\
\hline$>8$ & 76 & $63.9 \%$ & 43 & $36.1 \%$ & 119 & & & & \\
\hline \multicolumn{10}{|l|}{ Income } \\
\hline$\leq 3$ & 164 & $85.0 \%$ & 128 & $95.9 \%$ & 292 & $.121^{*}$ & 1.756 & .86 & 3.60 \\
\hline$>3$ & 27 & $15.0 \%$ & 12 & $30.8 \%$ & 39 & & & & \\
\hline \multicolumn{10}{|c|}{ Comorbidities } \\
\hline Yes & 103 & $58.5 \%$ & 73 & $41.5 \%$ & 155 & $.748^{*}$ & .931 & .60 & 1.44 \\
\hline No & 88 & $56.8 \%$ & 67 & $43.2 \%$ & 176 & & & & \\
\hline \multicolumn{10}{|l|}{ Employed } \\
\hline Yes & 104 & 65.8 & 54 & 34.2 & 158 & .004 & 1.904 & 1.22 & 2.97 \\
\hline No & 87 & 50.3 & 86 & 49.7 & 173 & & & & \\
\hline \multicolumn{10}{|c|}{ CD4 cell count } \\
\hline$\geq 500$ & 88 & $66.2 \%$ & 45 & $33.8 \%$ & 133 & $.023^{*}$ & & & \\
\hline $499-200$ & 73 & $54.5 \%$ & 61 & $45.5 \%$ & 134 & & & & \\
\hline$\leq 200$ & 30 & $46.9 \%$ & 34 & $53.1 \%$ & 64 & & & & \\
\hline \multicolumn{10}{|c|}{ Alcohol consumption } \\
\hline Yes & 100 & $59.5 \%$ & 68 & $40.5 \%$ & 168 & $.496^{*}$ & .859 & .56 & 1.33 \\
\hline No & 91 & $55.8 \%$ & 72 & $44.2 \%$ & 163 & & & & \\
\hline
\end{tabular}

Note: ${ }^{*}$ Chi-square test; ${ }^{\ddagger} \mathrm{Cl}=$ Confidence Interval.

performed to verify the association of sociodemographic, clinical, and behavioral variables using the chi-square test. Considering the symptoms of depression as a dependent variable, the significant variables in the univariate analysis were evaluated in the multivariate analysis. The multivariate analysis was performed using a multiple regression model. The dependent variable was the presence of depression (yes or no) and as independent variables were used CD4, sex, age, comorbidity, alcohol and employment, education, and income. For the selection of independent variables, the procedure "stepwise" was used, because in this process the variable schooling was not included. For input and output variables, the Wald statistics were used. For the chosen model we calculated the adjusted odds ratio and its confidence interval. For all the used tests we adopted the significance level of $5 \%($ alpha $=.05)$.

\section{RESULTS}

Of the 650 registered individuals, 331 PLWHA participated in the study. Of the total, some did not return to appointments scheduled during the study period, others changed their place of follow-up, and still others did not agree to participate. The participants were $50.5 \%$ men and $49.5 \%$ women. Ages ranged from 20 to 71 years old; the average age was 40 . In terms of socio-economic aspects, $64.1 \%$ had completed middle school and received from 1 to 3 times the minimum wage $(88.2 \%)$. In regard to clinical characteristics, $80.7 \%$ of the participants presented CD4 T cells greater than $200 / \mathrm{mm}^{3}$ and $53.2 \%$ did not have any co-morbidity or associated co-infection.

The prevalence of symptoms of depression and dysphoria found from the interviews was $42.3 \%$ (BDI > 11). The socio-demographic and clinical variables that presented a significant association with depressive symptoms were age $(p=.024$, being employed $(p=.004)$ and CD4 T count $(p=.023)$ (Table 1).

The multivariate analysis showed that individuals under the age of 40 were 1.8 times more likely (95\% CI [1.1, $2.8]$ ) to have depressive symptoms than those over 40 years old. The odds ratio for individuals who were employed indicated that they were 1.83 times $(95 \%$ CI $[1.1,2.8])$ more likely to develop depressive symptoms than those who were unemployed (Table 2).

The clinical aspects revealed that individuals with CD4 T cells less than $200 / \mathrm{mm}^{3}$ were 2.1 times more likely $(95 \%$ CI $[1.3,3.9])$ to develop depression than individuals with 
Table 2

Factors associated with symptoms of depression among PLWHA $(n=331)$

\begin{tabular}{|c|c|c|c|c|c|c|c|c|}
\hline \multirow{2}{*}{$\begin{array}{l}\text { Variable } \\
\text { Age }\end{array}$} & \multirow{2}{*}{$\frac{\text { Levels }}{>40}$} & \multirow{2}{*}{$\begin{array}{c}\text { Total } \\
105\end{array}$} & \multirow{2}{*}{$\begin{array}{c}p^{*} \\
.012\end{array}$} & \multirow[t]{2}{*}{$\mathrm{OR} \mathrm{raw}^{\dagger}$} & $95 \% \mathrm{Cl}^{\ddagger}$ & \multirow{2}{*}{$\frac{\text { OR adjusted }^{\S}}{1.89}$} & \multicolumn{2}{|c|}{$95 \% \mathrm{Cl}^{\ddagger}$} \\
\hline & & & & & & & 1.14 & 3.10 \\
\hline & $\leq 40$ & 226 & & 6.27 & & 1.00 & & \\
\hline \multirow{2}{*}{ Employed } & yes & 158 & .009 & 6.78 & & 1.83 & 1.16 & 2.88 \\
\hline & no & 173 & & & & 1.00 & & \\
\hline \multirow[t]{3}{*}{ CD4 T cells } & $\leq 200$ & 64 & .019 & 2.21 & 1.24 .07 & 1.64 & 1.00 & 2.76 \\
\hline & $200-499$ & 134 & & 1.63 & .92 .67 & 2.10 & 1.13 & 3.92 \\
\hline & $\geq 500$ & 133 & & & & 1.00 & & \\
\hline
\end{tabular}

Note: ${ }^{\star} p<0,05 ;+$ OR raw $=$ Odds ratio raw; ${ }^{\ddagger} \mathrm{Cl}=$ Confidence Interval; $\$$ OR adjusted $=$ Odds ratio adjusted.

CD4 T cells greater than $500 / \mathrm{mm}^{3}$. As for to variables having comorbidities and not consuming alcohol there was no statistically significant difference.

\section{DISCUSSION AND CONCLUSION}

Studies conducted in Brazil addressing PLWHA report that the prevalence of depressive symptoms may range from $25.8 \%$ to $53.5 \%$ (Dal-Bó, Manoel, Beltram Filho, Silva, Cardoso \& Cortez, 2015; Mello \& Malbergier, 2006; Reis et al., 2011; Schimitt \& Silva, 2009; Silveira et al., 2012). In this study, $42.3 \%$ of the individuals living with HIV/AIDS had depressive symptoms (BDI > 11). This finding corroborates a study carried out in Denmark, which presents a prevalence of 35\% (Slot, Sodemann, Gabel, Holmskov, Laursen \& Rodkjaer, 2015). The various instruments used to assess depressive symptoms and the different cut-off points authors adopt for the BDI (Sherr, Clucas, Harding, Sibley \& Catalan, 2011) may explain this variation. Nonetheless, depression is twice as frequent among PLWHA than in the general population (Ciesla \& Roberts, 2001).

An association between depression and clinical diseases occurs frequently, which may worsen both an individual's psychiatric condition and a clinical disease itself, leading to lower adherence to a therapeutic regimen, in addition to greater levels of morbidity and mortality. Depression is often under-diagnosed and under-treated, especially because depressive symptoms like fatigue, pain, and insomnia are common in chronic diseases. Additionally, there is a perception that depressive symptoms are merely adverse consequences of diseases (Teng, Humes \& Demetrio, 2005). The detection of depressive symptoms is often difficult due to the clinical manifestations of chronic diseases, such as fatigue, weight loss, and weakness, often found in PLWHA (Malbergier \& Schöffel, 2001).

A major challenge for health professionals treating PLWHA is to accurately distinguish between clinical depression and sadness arising from experiences, limitations, and difficulties of staff restructuring. This implies the need for an interdiscplinar care team to favor the implementation of an efficient and appropriate individual treatment plan. (Mello, Segurado \& Malbergier, 2010).

The socio-demographic aspects showed that depressive symptoms were associated with age, while individuals under the age of 40 were 1.8 times more likely (95\% CI [1.1, $2.8]$ ) to develop depressive symptoms than those over 40 years old. The prevalence of depressive symptoms in the population is higher in women, individuals up to 40 years old, less economically privileged people, and those who live without a partner (Boing, Melo, Boing, Moretti-Pires, Peres \& Peres, 2012).

A negative factor for depression in young adults is their inability to work (Wagner, Ghosh-Dastidar, Dickens, Nakasujja, Okello, Luyirika et al., 2012), which may interfere with their professional lives. In addition, feeling productive improves the quality of life of people living with HIV/AIDS (Freitas, Galvão, Araujo, Costa \& Lima, 2012). Being employed was a risk factor associated with depressive symptoms: employed individuals were 1.83 times (95\% CI $[1.1,2.8])$ more likely to develop depressive symptoms than those who were not employed). In this sense, people with worse socio-economic indicators are also more vulnerable to develop depressive symptoms. This finding is also observed in studies reporting that financial hardship is associated with depression among PLWHA (Rodkjaer, Laursen, Balle \& Sodemann, 2010; Silveira et al., 2012).

In Brazil, one study assessing the Quality of Life (QoL) of PLWHA reports that the higher the intensity of depressive symptoms, the worse the QoL score obtained from the domain Financial Worries of the HAT-QoL (Reis et al., 2011). The way income affects health may be understood by its use in acquiring goods and health services and in enabling access to healthcare, better living conditions, and education (Santos, Jacinto \& Tejada, 2012), which reinforces the importance of devising public policies of social inclusion and income generation for these individuals. One study conducted in Canada indicates that the social inclusion of PLWHA, due to their participation in the job market, was associated with improved QoL for both men and women with HIV. Among men, job stability was associated with improved mental health, which indicates the benefits of la- 
bor for one's mental health (Rueda, Raboud, Mustard, Bayoumi, Lavis \& Rourke, 2011).

This study's results concerning clinical aspects indicate there is a clear relationship between the immunological conditions of PLWHA and depressive symptoms, as described in other studies (Kaharuza et al., 2006; Silveira, Motta, Spack, Araujo \& Pupulin, 2007). The results show that individuals with CD4 T cells below $200 / \mathrm{mm}^{3}$ are 2.1 times more likely $(95 \% \mathrm{CI}[1.1,3.9])$ to develop depression than those with CD4 T cells above $500 / \mathrm{mm}^{3}$. These results suggest that psychosocial factors such as depression may affect clinical and immunological responses, as reported in other studies (Pence, Miller, Gaynes \& Eron, 2007), reinforcing the importance of the early detection and treatment of depression (Primeau, Avellaneda, Musselman, St Jean \& Illa, 2013).

Additionally, there was no association between having HIV/AIDS-related comorbidities and presenting depressive symptoms. However, Sarni et al. (2009) found that the chronic nature of the disease leads to the emergence of some comorbidities, such as lipodystrophy, which may affect the adherence to treatment and possibly lead to the development of depressive symptoms. Individual or group interventions to provide therapeutic support should be implemented among PLWHA who attend specialized services. Group activities implemented by multidisciplinary teams have been efficient because they qualify integral care delivery and empower PLWHA and their families (Santos, Munari \& Medeiros, 2009).

Nurses are the professionals present in largest numbers in specialized services providing care to PLWHA in Brazil (Ministry of Health, 2011) and they need to be qualified to promote interdisciplinary interventions designed to promote the mental health and treatment of these individuals. Such interventions have proven to be effective (Pyne et al., 2011). The implementation of group activities directed to promoting self-esteem and the sharing of experiences can broaden and strengthen social support sources, working as a protective factor against vulnerabilities in mental health.

Interventions should seek not only to prevent and treat of depressive events, but also to impede the consequences of depression on the quality of life of these individuals (Reis et al., 2011), as well as the impact depression has on the progression of the HIV infection (Malbergier \& Schöffel, 2001). So this study's results indicate that $42.3 \%$ of depressive symptoms among PLWHA show that risk factors include age, having a job and immunological condition.

It is necessary to acknowledge in clinical practice the situations that may lead people, especially women, living with HIV/AIDS to be vulnerable to mental disorders, and then to implement interdisciplinary actions to promote mental health, early detection and appropriate care of depressive symptoms in this population. There is a need to systematically assess the presence of depressive symptoms in PLWHA during clinical practice, since these are prevalent in this population. The use of protocols to screen depressive symptoms should also be incorporated by the health staff because early detection may improve the quality of life of these individuals. Health professionals should pay attention to factors that may contribute to the emergence of these symptoms and provide improved care to these individuals. These results can support healthcare directed to this population.

A limitation of this study is the absence of a sample calculation for the selection of participants and the use of a consecutive sample for convenience, and also the use of the screening instrument because the prevalence might be a result of the cut-off score. In addition, the subjects participated in a clinical follow-up at the time of the study.

\section{Funding}

None.

\section{Conflict of interests}

The authors declare they have no conflict of interest.

\section{REFERENCES}

Andrade, L., Gorenstein, C., Vieira Filho, A. H., Tung, T. C., Artes, R. (2001). Psychometric properties of the Portuguese version of the State-Trait Anxiety Inventory applied to college students: factor analysis and relation to the Beck Depression Inventory. Brazilian Journal of Medical and Biological Research, 34(3), 367-374. https://doi.org/10.1590/S0100-879X2001000300011

Boing, A. F., Melo, G. R., Boing, A. C., Moretti-Pires, R. O., Peres, K. G., Peres, M. A. (2012). Associação entre depressão e doenças crônicas: um estudo populacional. Revista de Saúde Pública, 46(4), 617-623.

Ciesla, J. A., Roberts, J. E. (2001). Meta-analysis of the relationship between HIV infection and risk for depressive disorders. The American Journal of Psychiatry, 158(5), 725-730.

Dal-Bó, M. J., Manoel, A. L., Beltram Filho, A. O., Silva, B. Q. T., Cardoso, Y. S., Cortez, J., et al. (2015). Depressive Symptoms and Associated Factors among People Living with HIV/AIDS. Journal of the International Association of Providers of AIDS Care, 14(2), 136-140.

Freitas, J. G., Galvão, M. T. G., Araujo, M. F. M., Costa, E., Lima, I. C. V. (2012). Enfrentamentos experienciados por homens que vivem com HIV/Aids no ambiente de trabalho. Revista da Escola de Enfermagem da USP, 46(3), 720-726.

Gomes-Oliveira, M. H., Gorenstein, C., Lotufo Neto, F., Andrade, L. H., Wang, Y. P. (2012). Validation of the Brazilian Portuguese version of the beck Depression Inventory-II in a Community sample. Revista Brasileira de Psiquiatria, 34(4), 389-394.

Israelski, D. M., Prentiss, D. E., Lubega, S., Balmas, G., Garcia, P., Muhammad, M., et al. (2007). Psychiatric co-morbidity in vulnerable populations receiving primary care for HIV/AIDS. AIDS Care, 19(2), 220-225.

Kaharuza, F. M., Bunnell, R., Moss, S., Purcell, D. W., Bikaako-Kajura, W., Wamai, N., et al. (2006). Depression and CD4 cell count among persons with HIV infection in Uganda. AIDS Behavior, 10(4 Suppl), 105-111.

Malbergier, A., Schöffel, A. C. (2001). Tratamento de depressão em indivíduos infectados pelo HIV. Revista Brasileira de Psiquiatria, 23(3), 160-167.

Mello, V. A., Malbergier, A. (2006). Depression in women infected with HIV. Revista Brasileira de Psiquiatri, 28(1), 10-17.

Mello, V. A., Segurado, A. A., Malbergier, A. (2010). Depression in women living with HIV: clinical and psychosocial correlates. Archives of Women's Mental Health, 13(3), 193-199. 
Ministry of Health. Departamento de DST, Aids e Hepatites Virais, Secretaria de Vigilância em Saúde (2012). Atenção em Saúde Mental nos Serviços Especializados em DST/Aids. Brasília, DF.

Ministry of Health. Departamento de DST, Aids e Hepatites Virais, Secretaria de Vigilância em Saúde (2011). Avaliação da qualidade dos serviços ambulatoriais do SUS que assistem adultos vivendo com o HIV/Aids no Brasil. Brasília, DF.

Pence, B. W., Miller, W. C., Gaynes, B. N., Eron, J. J. (2007). Psychiatric illness and virologic response in patients initiating highly active antiretroviral therapy. Journal of Acquired Immune Deficiency Syndrome, 44(2), 159-166.

Primeau, M. M., Avellaneda, V., Musselman, D., St Jean, G., Illa, L. (2013). Treatment of depression in individuals living with HIV/AIDS. Psychosomatics, 54(4), 336-344.

Pyne, J. M., Fortney, J. C., Curran, G. M., Tripathi, S., Atkinson, J. H., Kilbourne, A. M., et al. (2011). Effectiveness of collaborative care for depression in human immunodeficiency virus clinics. Archives International of Medicine, 171(1), 23-31.

Reis, R. K., Haas, V. J., Santos, C. B., Teles, S. A., Galvão, M. T. G., Gir, E. (2011). Symptoms of depression and quality of life of people living with HIV/AIDS. Revista Latino Americana de Enfermagem, 19(4), 874-881.

Rodkjaer, L., Laursen, T., Balle, N., Sodemann, M. (2010). Depression in patients with HIV is under-diagnosed: a cross-sectional study in Denmark. HIV Medicine, 11(1), 46-53.

Rueda, S., Raboud, J., Mustard, C., Bayoumi, A., Lavis, J. N., Rourke, S. B. (2011). Employment status is associated with both physical and mental health quality of life in people living with HIV. AIDS Care. 23(4), 435-443.

Santos, A. M. A., Jacinto, P. A., Tejada, C. A. O. (2012). Causalidade entre renda e saúde: uma análise através da abordagem de dados em painel com os estados do Brasil. Estudos Econômicos, 42(2), 229-261.

Santos, W., Munari, D. B., Medeiros, M. (2009). O grupo de mulheres que vivem e convivem com HIV/AIDS: um relato de experiência. Revista Eletrônica de Enfermagem, 11(4), 1043-1048.
Sarni, R. O. S., Souza, F. I. S., Battistini, T. R. B., Pitta, T. S., Fernandes, A. P., Tardini, P. C., et al. (2009). Lipodystrophy in children and adolescents with acquired immunodeficiency syndrome and its relationship with the antiretroviral therapy employed. Jornal de Pediatria, 85(4), 329-334.

Schimitt, J. H. L., Silva, R. M. (2009). Prevalence of depressive symptoms in patients with HIV/AIDS in a referral hospital in the city of Florianóplois-SC. Arquivos Catarinenses de Medicina, 38(2), 90-97.

Sherr, L., Clucas, C., Harding, R., Sibley, E., Catalan, J. (2011). HIV and depression-a systematic review of interventions. Psychology Health Medicine, 16(5), 493-527.

Silva, L. M. S., Moura, M. A. V., Pereira, M. L. D. (2013). Cotidiano de mulheres após contágio pelo hiv/aids: subsídios norteadores da assistência de enfermagem. Texto \& contexto - enfermagem, 22(2), 335-342.

Silveira, L. V., Motta, D. D., Spack, M., Araujo, S. M., Pupulin, A. R. T. (2007). Depressão, estresse e alexitimia em pacientes com infecção pelo vírus HIV. Acta Scientiarum - Health Sciences, 29(1), 67-71.

Silveira, M. P. T., Guttier, M. C., Pinheiro, C. A. T., Pereira, T. V. S., Cruzeiro, A. L. S., Moreira, L. B. (2012). Depressive symptoms in HIV-infected patients treated with highly active antiretroviral therapy. Revista Brasileira de Psiquiatria, 34(2), 162-167.

Slot, M., Sodemann, M., Gabel, C., Holmskov, J., Laursen, T., Rodkjaer, L. (2015). Factors associated with risk of depression and relevant predictors of screening for depression in clinical practice: a cross-sectional study among HIV-infected individuals in Denmark. HIV Medicine, 16(7), 393-402.

Teng, C. T., Humes, E. C., Demetrio, F. N. (2005). Depressão e comorbidades clínicas. Revista de Psiquiatria Clínica, 32(3), 149-159.

Wagner, G. J, Ghosh-Dastidar, B., Dickens, A., Nakasujja, N., Okello, E., Luyirika, E., Musisi, S. (2012). Depression and its relationship to work status and income among HIV clients in Uganda. World Journal of AIDS, 2(3), 126-134.

World Health Organization (2010). Depression 2010. Access 15 September, 2016, from http://www.who.int/topics/depression/en/ 